\title{
Design and synthesis of new bis-hydrazones and pyridine bis-hydrazones: application in the asymmetric Diels-Alder reaction
}

\author{
David Monge, Antonio Bermejo, Juan Vázquez, Rosario Fernández, * \\ and José M. Lassaletta*
}

Instituto de Investigaciones Químicas (CSIC-US), C/ Américo Vespucio 49, 41092 Sevilla, Spain and Departamento de Química Orgánica, C/ Prof. García González, 1, 41012 Sevilla, Spain

E-mail:ffernan@us.es, jmlassa@iiq.csic.es

\section{Dedicated to Prof. Richard R. Schmidt on the occasion of his $78^{\text {th }}$ anniversary}

\begin{abstract}
The design of two different types of new chiral bis-hydrazones 5 (bidentate $N, N$ ligands, type A) and pyridine bis-hydrazones 7 ('pincer' $N, N, N$ ligands, type $B$ ) is discussed. Preliminary results on the copper(II)-catalyzed Diels-Alder reaction of $N$-(E)-crotyloxazolidin-2-one (8) with cyclopentadiene (9) revealed that the $(2 S, 6 S)$-2,6-diphenylpiperidine $C_{2}$-symmetric substructure in pyridine bis-hydrazone ligand $\mathbf{7 c}$ is the key design element leading to good enantioselectivities.
\end{abstract}

Keywords: Bis-hydrazones, N-ligands, asymmetric catalysis, Diels-Alder reaction

\section{Introduction}

The design and synthesis of new families of chiral ligands has been the starting task for the many particular pieces of research that have contributed to the spectacular growth of asymmetric catalysis during the last 30 years. ${ }^{1}$ Currently, there is a growing interest in nitrogen-based ligands, ${ }^{2}$ which offer several distinct advantages compared to the widespread phosphorous-based ligands. Thus, nitrogen compounds offer an extraordinary structural variability, with many compounds available from cheap natural sources such as aminoacids, alkaloids, etc (the 'chiral pool'). Moreover, they are in general easy to synthesize and manipulate, and possess fair stability, for instance against the oxidation that is a common problem in phosphines, and this stability also provides recycling opportunities by different methods. In particular, the chiral $\mathrm{N}\left(\mathrm{sp}^{2}\right)$-based privileged bipyridine $(\mathbf{I}),{ }^{3}$ bis-imine $(\mathbf{I I}),{ }^{4}$ bis-oxazoline (III) ${ }^{5}$ or pyridine bisoxazoline (IV) ${ }^{6}$ ligands (Figure 1) have enabled the development of a vast number of asymmetric reactions. 


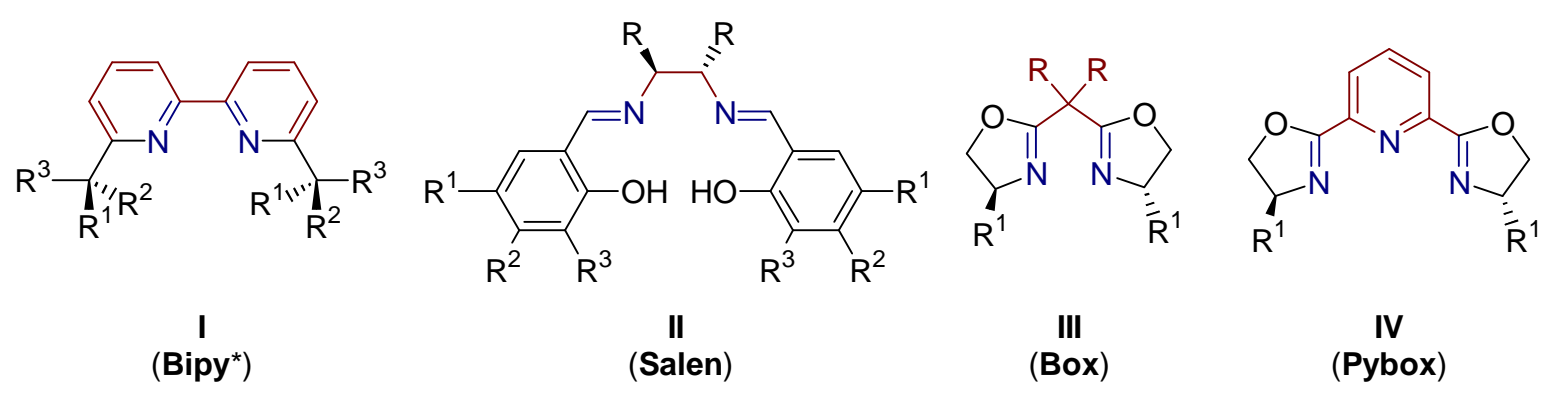

Figure 1. Privileged chiral ligands based on $\mathrm{sp}^{2}$ nitrogens.

During the last few years we have accumulated some knowledge about the synthesis, reactivity and structural aspects of the chemistry of $N, N$-dialkylhydrazones. ${ }^{7}$ These compounds, viewed as $N$-dialkylamino-substituted imines, exhibit a higher thermal stability than $N$ alkyl(aryl) derivatives as a result of the $n \rightarrow \pi$ conjugation. The behaviour of the $\mathrm{C}=\mathrm{N}$ bond is strongly dependent on the structure of the dialkylamino moiety, which in turn controls the efficiency of the conjugation. This group may also incorporate structural elements to modulate the steric crowding around the coordination site and eventually incorporate additional coordination positions. In addition, a variety of chiral, sterically tunable hydrazines are available from inexpensive starting materials such as amino acids (particularly proline), ${ }^{8}$ carbohydrates, ${ }^{9}$ diketones ${ }^{7 \mathrm{f}}$ and others. ${ }^{10}$ In summary, the electronic characteristics and structural variability of hydrazones make these compounds to appear as an appealing class of potentially useful ligands. Despite these peculiarities, a literature survey revealed very few examples on the use of chiral hydrazones as ligands in asymmetric catalysis. ${ }^{11}$ Therefore, we decided to explore new nitrogen ligands based on chiral glyoxal bis-hydrazones $\mathbf{V}$. We initially reported on the development of $\left[\mathrm{Cu}(\mathrm{OTf})_{2} / \mathbf{V}\right]$ catalysts, in which the introduction of $C_{2}$-symmetric dialkylamino groups, making rotations around $\mathrm{N}-\mathrm{N}$ bonds inconsequential, proved to be key design strategy to achieve high enantioselectivities in asymmetric Diels-Alder reactions ${ }^{12}$ (Figure 2). Moreover, we have recently shown that $\left[\mathrm{PdCl}_{2} / \mathbf{V}\right]$ complexes, designed on the basis of a similar strategy, are highly active and selective precatalysts in Suzuki-Miyaura cross-couplings for the enantioselective synthesis of biaryls. ${ }^{13}$

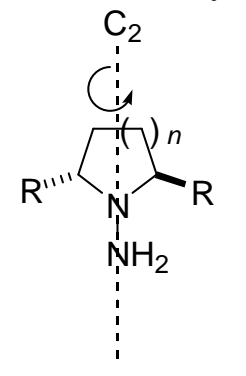

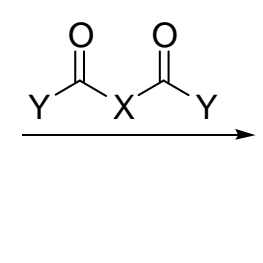

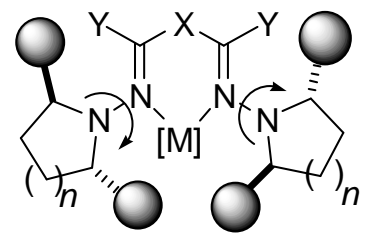

Inconsequential N-N bond rotations

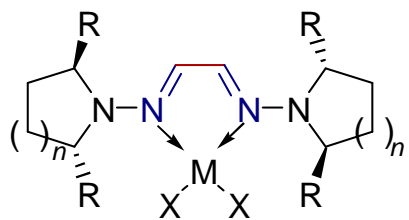

$\mathrm{MX}_{2} / \mathbf{V}$ Complex

Figure 2. $C_{2}$-symmetric glyoxal bis-hydrazones design. 
The proposed ligands $\mathbf{V}$ possess several interesting features: (a) availability in both enantiomeric forms, (b) bidentate coordination ability, (c) $C_{2}$-symmetry, simplifying the analysis of the stereochemical outcome, (d) limited flexibility around $\mathrm{N}-\mathrm{N}$ bonds, providing an adequate chiral environment for square-planar complexes and a considerable steric crowding, (e) a high electronic density at $\mathrm{N}$ provided by $n \rightarrow \pi$ conjugation in the bis-hydrazone ligand compared with the 1,4-diazabutadiene ligands. ${ }^{14}$ Despite the success achieved in the Diels Alder and SuzukiMiyaura reactions mentioned above, the bis-hydrazones used have limitations related to the thermal and chemical stability of some of their metal complexes, on one hand, and the absence of a modular design, on the other, that in principle provide few tools for the modification of their structures. In continuation of our research on ligand design for asymmetric catalysis, herein we present the synthesis of new chiral bis-hydrazones with distinct properties complementary to those of the glyoxal bis-hydrazones previously assessed.

\section{Results and Discussion}

\section{Design of new bis-hydrazones (type A) and pyridine bis-hydrazones (type B)}

As an extension of our work in this field, we aim to expand the structural diversity of the ligands previously developed by introducing different spacers between the azomethine carbons. In addition to glyoxal bis-hydrazones (no spacer), the new designs comprise 1,1diformylcyclopentane-derived bis-hydrazones (cyclopentylidene spacer, type A) and 2,6diformylpyridine derived bis-hydrazones (pyridine spacer, type B) (Figure 3). We envisioned that the presence of a carbon atom spacer between $\mathrm{C}=\mathrm{N}$ groups, leading to six-membered chelates, should result in a closer chiral environment as the dialkylamino group $\mathrm{NR}_{2}$ approaches the metal center in the active [type A ligand/M] complexes. Moreover, the corresponding complexes might have electronic properties that differ in the independence of the hydrazone $\pi$ systems, interrupted here by a quaternary carbon atom.

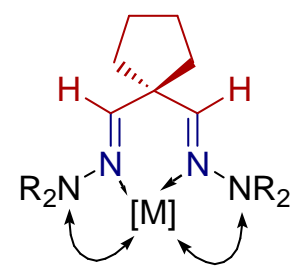

Type A

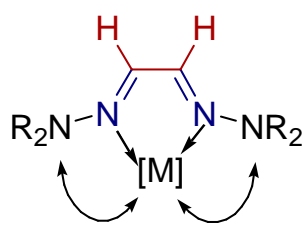

Original design

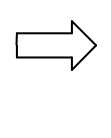

$\Rightarrow$ Six membered chelate

$\Rightarrow$ Shorter M-NR 2 distances

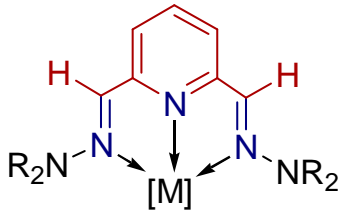

Type B

$\Rightarrow$ Tridentate "pincer" ligand

$\Rightarrow$ Larger binding site

Figure 3. Novel bidentate bis-hydrazones (type A) and 'pincer' pyridine bis-hydrazones (type B). 
On the other hand, type $\mathbf{B}$ ligands consist of a pyridine ring flanked by two azomethine carbons. In this design, the hydrazone groups play the role of the oxazolidine moieties in the well established Pybox 'pincer' ligands, offering alternatives concerning structure variability. From these pyridine bis-hydrazones acting in tridentate coordination mode, more stable and rigid [type B ligand/M] complexes are expected. Moreover, the binding site should be suitable to host lanthanide cations, which have revealed extraordinary activity in many reactions of interest. ${ }^{15}$ The availability of numerous families of chiral hydrazines allows the direct synthesis of a wide range of hydrazones. For example, proline derivatives bearing 'hemilabile' coordination positions (such as methoxy groups) might be beneficial for the effectiveness of the catalyst, helping to generate and temporarily stabilize coordination vacancies on the metal center, while $C_{2}-$ symmetric hydrazines essentially create stable chiral environments. ${ }^{16}$ Importantly, it is possible to access both enantiomers of the ligands object of study.

\section{Synthesis of chiral hydrazines}

The synthesis of the required enantiomerically pure hydrazines was accomplished by following different methods. Thus, $(S)$-2-(methoxymethyl)pyrrolidin-1-amine $(S A M P, 1 \mathbf{1 a})$ and related chiral auxiliary $(S)$-2-(methoxydiphenylmethyl)pyrrolidin-1-amine $(S A P P, \mathbf{1 b})$ were synthesized following known procedures described by Enders and co-workers ${ }^{8}$ Figure 4$)$.

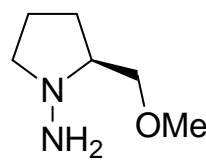

$1 \mathrm{a}$

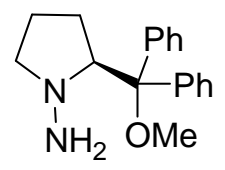

$1 \mathbf{b}$

Figure 4. Proline-derived hydrazines.

On the other hand, $C_{2}$-symmetric hydrazines $\mathbf{3 a , b}$ were prepared on a multigram scale from known diols 2a,b (synthesized from diketones by oxazaborolidine-catalyzed reduction, Scheme $1)^{17}$ after mesylation and reaction with hydrazine hydrate as described previously. ${ }^{12}(2 R, 5 R)-2,5-$ Dimethylpyrrolidin-1-amine 3c was obtained from commercially available 1,4-diol $\mathbf{2 c}$ following a similar procedure. ${ }^{18}$

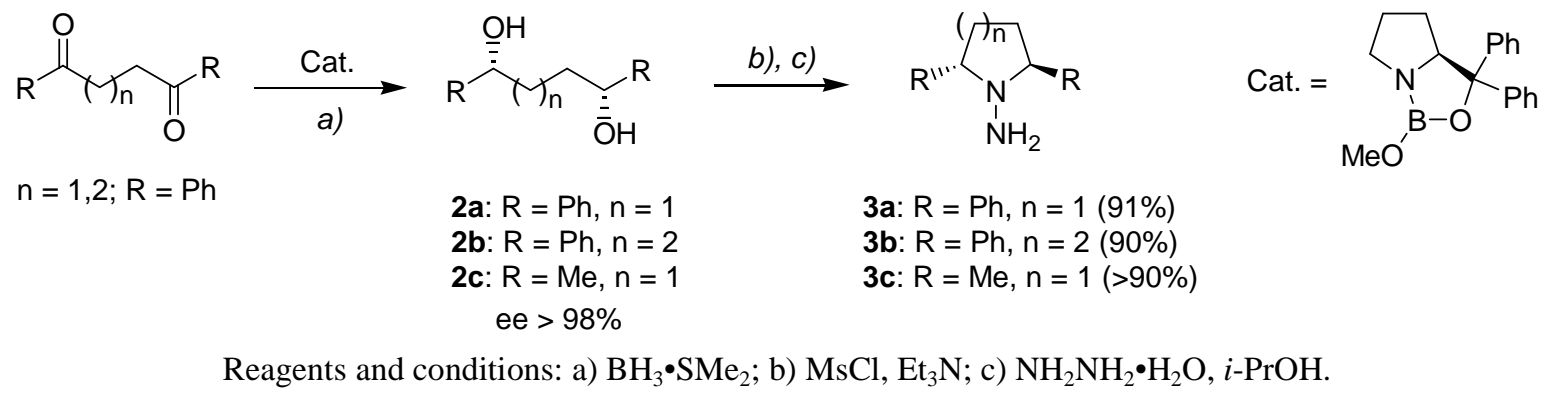

Scheme 1. Synthesis of $C_{2}$-symmetric hydrazines 3. 


\section{Synthesis of bis-hydrazones 5 (N,N ligands, type A)}

Type $\mathbf{A}$ bis-hydrazones $\mathbf{5 a - c}$ were readily synthesized by simple condensation of hydrazines $\mathbf{1 b}$ and 3a,b with cyclopentane-1,1-dicarbaldehyde $\mathbf{4}$ in $\mathrm{MeOH}$ at room temperature, as outlined in Scheme 2. For the synthesis of dialdehyde 4, a procedure described by Kirchner and coworkers ${ }^{19}$ was followed.
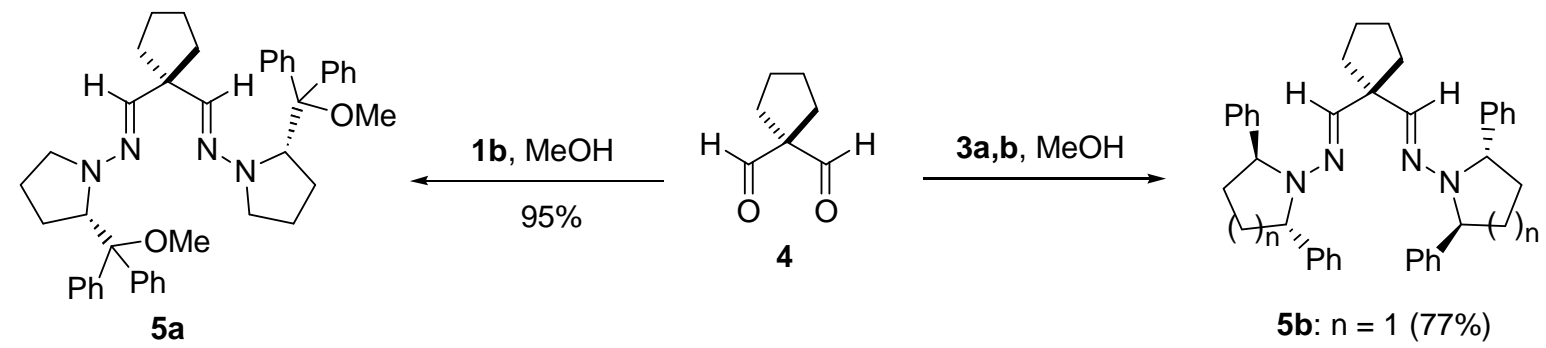

$5 b: n=1(77 \%)$

$5 c ; n=2(52 \%)$

Scheme 2. Synthesis of bis-hydrazones 5 .

\section{Synthesis of pyridine bis-hydrazones 7 (N,N,N ligands, type B)}

For type B pyridine bis-hydrazones 7a-d, a similar condensation protocol involving hydrazines 1a, 3a-c and pyridine-2,6-dicarbaldehyde $\mathbf{6}$ afforded the desired products in good yields (Scheme 3 ). In this system, slow addition of dialdehyde over hydrazine solutions was required to increase the formation of bis-hydrazones, while alternative conditions afforded lower yields and mixtures containing mono-hydrazones.

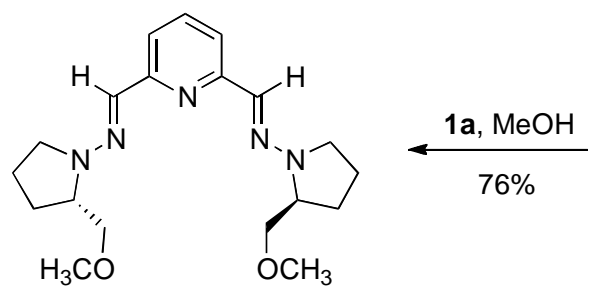

$7 a$

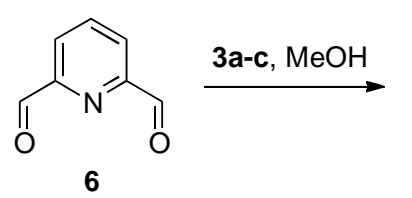

6

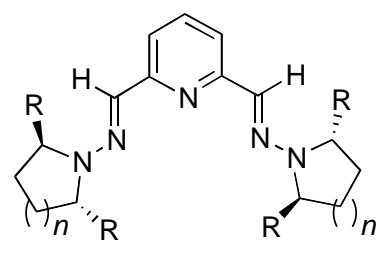

7b: $\mathrm{R}=\mathrm{Ph}, n=1(74 \%)$ 7c: $\mathrm{R}=\mathrm{Ph}, n=2(60 \%)$ 7d: $\mathrm{R}=\mathrm{Me}, n=1(80 \%)$

Scheme 3. Synthesis of pyridine bis-hydrazones 7.

\section{Application in the asymmetric Diels-Alder reaction}

The enantioselective Diels-Alder reaction ${ }^{20}$ was chosen as the platform to evaluate the efficiency of the new ligands, enabling a direct comparison between glyoxal bis-hydrazones and the new bis-hydrazones synthesized. It should be noted that using $\left[\mathrm{Cu}(\mathrm{OTf})_{2} / \mathbf{V}\right]$ catalyst $[\mathbf{V}$ derived from $(2 S, 5 S)$-2,5-diphenylpyrrolidine], it was possible to perform the highly enantioselective (ee > $90 \%$ ) Diels-Alder reaction between $N$-acryloyloxazolidin-2-one and a wide range of dienes 
(flexible and even acyclic dienes). ${ }^{12}$ Despite these excellent results, a major drawback is that the $\left[\mathrm{Cu}(\mathrm{OTf})_{2} / \mathbf{V}\right]$ complexes are thermally unstable above $-30{ }^{\circ} \mathrm{C}$ and, therefore, the extension to more substituted dienophiles was not possible. Taking this limitation into account, we decided to use the reaction of $\mathrm{N}$-crotonyloxazolidin-2-one $\mathbf{8}$ with cyclopentadiene $\mathbf{9}$ as the model system. The preliminary results of the model reaction were collected using $\left[\mathrm{M}(\right.$ bis-hydrazone $\left.)(\mathrm{OTf})_{\mathrm{x}}\right]$, generated in situ by stirring a solution of the corresponding ligand ( 5 or $7 ; 11 \mathrm{~mol} \%)$ with the desired metal triflate $\left[\mathrm{Sc}(\mathrm{OTf})_{3}, \mathrm{Mg}(\mathrm{OTf})_{2}, \mathrm{Zn}(\mathrm{OTf})_{2}, \mathrm{Cu}(\mathrm{OTf})_{2} ; 10 \mathrm{~mol} \%\right]$, in dry toluene at room temperature (Table 1). Under these conditions, bis-hydrazones 5 afforded disappointing results. Among the screened metal salts, only $\mathrm{Sc}(\mathrm{OTf})_{3}$ resulted in complete reactions in some cases, the reaction giving the endo cycloadduct 10, although without measurable enantioselectivities (entries 1,3). Use of $\mathrm{Mg}^{2+}, \mathrm{Zn}^{2+}$, and $\mathrm{Cu}^{2+}$ complexes afforded partial conversions. In contrast, ligands 7 in combination with $\mathrm{Cu}(\mathrm{OTf})_{2}$ (entries 4,5,7 and 9) or $\mathrm{Zn}(\mathrm{OTf})_{2}$ (entries 6, 8 and 10) showed better catalytic performance. Thus, employing $\left[\mathrm{Cu}(\mathrm{OTf})_{2} / 7\right]$ catalyst containing pyrrolidine based $N, N$-dialkylamino groups $(\mathbf{7 a}, 7 \mathbf{b}$ and $\mathbf{7 d})$,

Table 1. Screening of catalysts for the asymmetric Diels-Alder of 8 with $\mathbf{9}^{\mathrm{a}}$
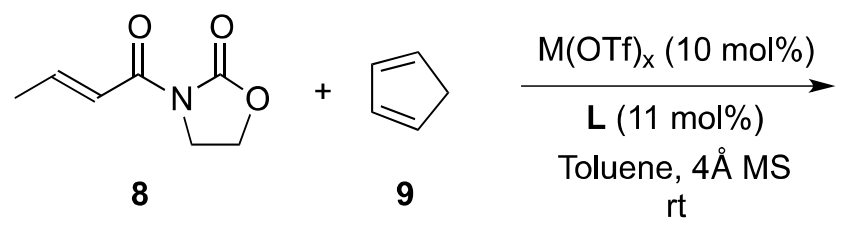

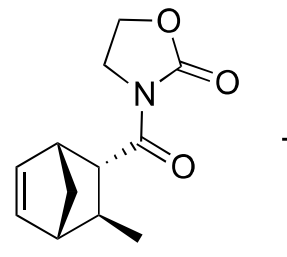

$(1 R, 2 R, 3 S, 4 S)-10$

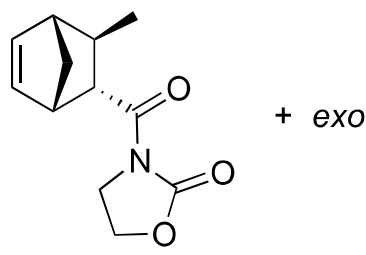

$(1 S, 2 S, 3 R, 4 R)-10$

\begin{tabular}{cccccc}
\hline Entry & Ligand & $\mathrm{M}(\mathrm{OTf})_{\mathrm{x}}$ & $\begin{array}{c}\text { Conversion }^{\mathrm{b}} \\
(\%)\end{array}$ & endo:exo $^{c}$ & e.r. $^{c}$ \\
\hline 1 & $\mathbf{5 a}$ & $\mathrm{Sc}(\mathrm{OTf})_{3}$ & $>95$ & $84: 16$ & rac \\
2 & $\mathbf{5 b}$ & $\mathrm{Sc}(\mathrm{OTf})_{3}$ & 50 & $84: 16$ & rac \\
3 & $\mathbf{5 c}$ & $\mathrm{Sc}(\mathrm{OTf})_{3}$ & $>95$ & $85: 15$ & rac \\
4 & $\mathbf{7 a}$ & $\mathrm{Cu}(\mathrm{OTf})_{2}$ & $>95$ & $75: 25$ & rac \\
5 & $\mathbf{7 b}$ & $\mathrm{Cu}(\mathrm{OTf})_{2}$ & $>95$ & $94: 6$ & rac \\
6 & $\mathbf{7 b}$ & $\mathrm{Zn}(\mathrm{OTf})_{2}$ & 40 & $97: 3$ & $55: 45$ \\
$\mathbf{7}$ & $\mathbf{7 c}$ & $\mathbf{C u}(\mathbf{O T f})_{2}$ & $\mathbf{5 0}$ & $\mathbf{7 8 : 2 2}$ & $\mathbf{6 8 : 3 2}$ \\
8 & $\mathbf{7 c}$ & $\mathbf{Z n}(\mathbf{O T f})_{2}$ & $\mathbf{5 0}$ & $\mathbf{9 0 : 1 0}$ & $\mathbf{8 0 : 2 0}$ \\
9 & $\mathbf{7 d}$ & $\mathrm{Cu}(\mathrm{OTf})_{2}$ & $>95$ & $85: 15$ & rac \\
10 & $\mathbf{7 d}$ & $\mathrm{Zn}(\mathrm{OTf})_{2}$ & 60 & $87: 13$ & rac \\
\hline
\end{tabular}

${ }^{a}$ Reactions were carried out in dry toluene using $8(0.2 \mathrm{mmol})$, ligand 5 or 7 (11 mol\%), $\mathrm{M}(\mathrm{OTf})_{\mathrm{x}}(10 \mathrm{~mol} \%)$, and $9(0.8 \mathrm{mmol})$ in the presence of $4 \AA$ molecular sieves for $90 \mathrm{~h} .{ }^{\mathrm{b}}$ Determined by ${ }^{1} \mathrm{H}$ NMR. ${ }^{\mathrm{c}}$ Determined by HPLC on chiral stationary phases. 
cycloadduct $\mathbf{1 0}$ was obtained with excellent conversions (>95\%, entries 4, 5 and 9), diastereoselectivities from moderate (endo:exo, 75:25 for 7a) to good (endo:exo, 94:6 for 7b), albeit in racemic form in all cases. The endo:exo ratio was slightly superior using $\mathrm{Zn}(\mathrm{OTf})_{2}$ in combination with 7b and 7d (entries 6 and 10), although lower conversions of racemic-endo-10 were observed. Interestingly, employing piperidine based $\left[\mathrm{Cu}(\mathrm{OTf})_{2} / 7 \mathrm{c}\right]$, the reaction proceeds with lower conversion (50\%, entry 7), moderate diastereoselectivity (endo:exo, 78:22) and increased enantioselectivity $(68: 32$ e.r. $)$, while $\left[\mathrm{Zn}(\mathrm{OTf})_{2} / 7 \mathrm{c}\right]$ afforded the desired cycloadduct $(1 R, 2 R, 3 S, 4 S)-10$ with a similar conversion (50\%, entry 8), better diastereoselectivity (endo:exo, 90:10) and promising yet moderate enantioselectivity (up to 80:20 e.r.).

Having confirmed pyridine bis-hydrazone 7c in combination with $\mathrm{Cu}(\mathrm{OTf})_{2}$ or $\mathrm{Zn}(\mathrm{OTf})_{2}$ as the best catalytic system in terms of enantioselectivity, we started optimizing the reaction conditions. First, we screened several solvents as outlined in Table 2. Conducting the reaction in halogenated solvents like $\mathrm{CH}_{2} \mathrm{Cl}_{2}$ or $\mathrm{CHCl}_{3}$ had a detrimental effect on the reactivity of the reaction. Thus, in $\mathrm{CH}_{2} \mathrm{Cl}_{2}$ only trace amounts of cycloadduct were detected (entries 3 and 4), while use of $\mathrm{CHCl}_{3}$ afforded the product in $20 \%$ yield (entries 5 and 10). In toluene, the better solvent for the $\mathrm{Zn}$ (II)-catalyzed reaction, the reactivity was moderate (entries 1 and 2), but use of $\mathrm{Bu}_{2} \mathrm{O}$ as a coordinating solvent (entries 6 and 7) enhanced the catalytic activity and selectivity of the $\left[\mathrm{Cu}(\mathrm{OTf})_{2} / 7 \mathrm{c}\right]$ catalyst, giving 10 in $90 \%$ yield, 91:9 endo:exo ratio and 83:17 e.r. Next, experiments were performed in non-dried toluene (entries 8 and 9) or $\mathrm{Bu}_{2} \mathrm{O}$ (entries 11 and 12).

Table 2. Optimization for the asymmetric Diels-Alder of $\mathbf{8}$ with $\mathbf{9}$ catalyzed by $\mathbf{7} \mathbf{c}^{\mathrm{a}}$

\begin{tabular}{cccccc}
\hline Entry & $\mathrm{M}(\mathrm{OTf})_{2}$ & Solvent & Yield $^{\mathrm{b}}(\%)$ & endo:exo $^{c}$ & e.r. $^{c}$ \\
\hline 1 & $\mathrm{Cu}(\mathrm{OTf})_{2}$ & Toluene & 40 & $78: 22$ & $68: 32$ \\
2 & $\mathrm{Zn}(\mathrm{OTf})_{2}$ & Toluene & 40 & $90: 10$ & $80: 20$ \\
3 & $\mathrm{Cu}(\mathrm{OTf})_{2}$ & $\mathrm{CH}_{2} \mathrm{Cl}_{2}$ & $\mathrm{nr}$ & - & - \\
4 & $\mathrm{Zn}(\mathrm{OTf})_{2}$ & $\mathrm{CH}_{2} \mathrm{Cl}_{2}$ & $\mathrm{nr}$ & - & - \\
5 & $\mathrm{Cu}(\mathrm{OTf})_{2}$ & $\mathrm{CHCl}_{3}$ & 20 & $85: 15$ & $83: 17$ \\
6 & $\mathrm{Cu}(\mathrm{OTf})_{2}$ & $\mathrm{Bu}_{2} \mathrm{O}$ & 90 & $91: 9$ & $83: 17$ \\
7 & $\mathrm{Zn}(\mathrm{OTf})_{2}$ & $\mathrm{Bu}_{2} \mathrm{O}$ & 30 & $81: 19$ & $77: 13$ \\
$8^{\mathrm{d}}$ & $\mathrm{Cu}(\mathrm{OTf})_{2}$ & $\mathrm{Toluene}^{\mathrm{d}}$ & 95 & $92: 8$ & $87: 13$ \\
$9^{\mathrm{d}}$ & $\mathrm{Zn}(\mathrm{OTf})_{2}$ & $\mathrm{Toluene}^{\mathrm{d}}$ & 40 & $84: 16$ & $80: 20$ \\
$10^{\mathrm{d}}$ & $\mathrm{Cu}(\mathrm{OTf})_{2}$ & $\mathrm{CHCl}_{3}$ & 20 & $88: 12$ & $71: 29$ \\
$11^{\mathrm{d}}$ & $\mathrm{Cu}(\mathrm{OTf})_{2}$ & $\mathrm{Bu}_{2} \mathrm{O}$ & 60 & $93: 7$ & $86: 14$ \\
$12^{\mathrm{d}}$ & $\mathrm{Zn}(\mathrm{OTf})_{2}$ & $\mathrm{Bu}_{2} \mathrm{O}$ & $\mathrm{nr}$ & - & - \\
\hline
\end{tabular}

${ }^{\mathrm{a}}$ Reactions were performed in dry solvent using $8(0.2 \mathrm{mmol})$, ligand 7c $(11 \mathrm{~mol} \%), \mathrm{M}(\mathrm{OTf})_{2}$ (10 mol\%), and $9(0.8 \mathrm{mmol})$ in the presence of $4 \AA$ molecular sieves for $90 \mathrm{~h}^{\mathrm{b}}{ }^{\mathrm{b}}$ Isolated yield. ${ }^{\mathrm{c}}$ Determined by HPLC on chiral stationary phases. ${ }^{\mathrm{d}}$ Reactions were performed in non-dried solvents. 
Interestingly, the eventual presence of water provided different results. Thus, employing $\left[\mathrm{Zn}(\mathrm{OTf})_{2} / 7 \mathrm{c}\right]$ complex in non-dried toluene (entry 9) afforded slightly worse results, whereas, non-dried $\mathrm{Bu}_{2} \mathrm{O}$ (entry 12) provoked a dramatic lost of catalytic activity. Remarkably, $\left[\mathrm{Cu}(\mathrm{OTf})_{2} / 7 \mathrm{c}\right]$ in non-dried $\mathrm{Bu}_{2} \mathrm{O}$ (entry 11 ) provided slightly better diastereo- and enantioselectivity, albeit with moderate yield $(60 \%)$. Noteworthy, $\left[\mathrm{Cu}(\mathrm{OTf})_{2} / 7 \mathrm{c}\right]$ in non-dried toluene (entry 8) gave endo $(1 R, 2 R, 3 S, 4 S)$-10 with excellent yield (95\%), and good diastereoselectivity (endo:exo, 92:8) and enantioselectivity (87:13 e.r.), suggesting that water might play an important role on the reactive catalyst-substrate species. In order to shed light over these experimental results we decided to study different hydrated copper (II) salts $\left[\mathrm{CuCl}_{2} \cdot 2 \mathrm{H}_{2} \mathrm{O}\right.$, $\left.\mathrm{Cu}(\mathrm{OAc})_{2} \cdot \mathrm{H}_{2} \mathrm{O}, \quad \mathrm{Cu}\left(\mathrm{BF}_{4}\right)_{2} \cdot 6 \mathrm{H}_{2} \mathrm{O}, \quad \mathrm{CuC}_{2} \mathrm{O}_{4} \cdot 1 / 2 \mathrm{H}_{2} \mathrm{O}, \quad \mathrm{Cu}\left(\mathrm{ClO}_{4}\right)_{2} \cdot 6 \mathrm{H}_{2} \mathrm{O}\right]$ in dry toluene. Unfortunately, only $\mathrm{Cu}\left(\mathrm{ClO}_{4}\right)_{2} \cdot 6 \mathrm{H}_{2} \mathrm{O}$ allowed us to obtain the cycloaddition endo product $\mathbf{1 0}$ with good yield (90\%) and diastereoselectivity (endo:exo, 92:8), although with lower enantiomeric ratio $(62: 38)$ than that obtained with $\mathrm{Cu}(\mathrm{OTf})_{2}$ in undried toluene.

\section{Conclusions}

In summary, we have reported the synthesis of new chiral bis-hydrazones $\mathbf{5}$ and pyridine bishydrazones 7. Preliminary results on the copper(II)-catalyzed Diels-Alder reaction of $N$ crotonyloxazolidin-2-one $\mathbf{8}$ with cyclopentadiene 9 revealed that $C_{2}$-symmetric dialkylamino substructures in pyridine bis-hydrazones $\mathbf{7}$ is the key combination. In contrast to the results previously collected with related catalysts ${ }^{12,13}$ or auxiliaries, ${ }^{21}$ the piperidine-based bis-hydrazone 7c provides better chiral environment than the pyrrolidine-based $\mathbf{7 b}$, a fact that can be partly attributed to the higher conformational flexibility afforded by piperidine rings. Further applications of these nitrogen ligands, especially aqua-complexes, in metal-catalyzed organic reactions are currently being explored in our laboratories.

\section{Experimental Section}

General. ${ }^{1} \mathrm{H}$ NMR spectra were recorded at $300 \mathrm{MHz}, 400 \mathrm{MHz}$ or $500 \mathrm{MHz} ;{ }^{13} \mathrm{C}$ NMR spectra were recorded at $75 \mathrm{MHz}, 100 \mathrm{MHz}$ or $125 \mathrm{MHz}$, with the solvent peak used as the internal standard. Analytical thin layer chromatography (TLC) was performed on $0.25 \mathrm{~mm}$ silica gel $60-\mathrm{F}$ plates and visualized by ultraviolet irradiation and $\mathrm{KMnO}_{4}$, anisaldehyde or phosphomolybdic acid stains. Optical rotations were measured on a Perkin-Elmer $341 \mathrm{MC}$ polarimeter. The enantiomeric ratios (e.r.) of the products were determined by chiral stationary-phase HPLC (Daicel Chiralpak OD column). Unless otherwise noted, analytical grade solvents and commercially available reagents, or catalysts, were used without further purification. Solvents were purified and dried by standard procedures. For flash chromatography (FC) silica gel (0.040$0.063 \mathrm{~mm}$ ) was used. 
The following compounds were prepared following literature procedures: $(S)$-2-(methoxymethyl)pyrrolidin-1-amine $\quad(\mathbf{1 a}),{ }^{8 \mathrm{a}}(S)$-2-(methoxydiphenylmethyl)pyrrolidin-1-amine $\quad(\mathbf{1 b}){ }^{8 \mathrm{~b}}$ $(2 S, 5 S)$-2,5-diphenylpyrrolidin-1-amine $\quad(\mathbf{3 a}),{ }^{12} \quad(2 S, 6 S)$-2,6-diphenylpiperidin-1-amine $\quad(\mathbf{3 b}),{ }^{12}$ $(2 R, 5 R)$-2,5-dimethylpyrrolidin-1-amine $(3 \mathbf{c}),{ }^{18}$ cyclopentane-1,1-dicarbaldehyde $(\mathbf{4}),{ }^{19}$ (E)-3(but-2-enoyl)oxazolidin-2-one $(\mathbf{8}){ }^{22}$

\section{General procedure for the synthesis of bis-hydrazones (5)}

A solution of cyclopentane-1,1-dicarbaldehyde $(4,378 \mathrm{mg}, 3 \mathrm{mmol})$ in $\mathrm{MeOH}(0.5 \mathrm{~mL})$ was added to a solution of hydrazine $(8 \mathrm{mmol})$ in $\mathrm{MeOH}(1 \mathrm{~mL})$ at room temperature. After two hours stirring, the solvent was removed under reduced pressure, and the residue was purified by $\mathrm{FC}$ on silica gel (Hexane/ $\left.\mathrm{Et}_{2} \mathrm{O}\right)$ affording the pure bis-hydrazone.

Bis-hydrazone 5a. Following the general procedure, column chromatography (10:1 Hexane$\left.\mathrm{Et}_{2} \mathrm{O}\right)$ afforded 5a $(1.8 \mathrm{~g}, 95 \%)$ as a white solid. $[\alpha]_{\mathrm{D}}^{20}-190.5\left(c 1.0, \mathrm{CHCl}_{3}\right) . \mathrm{RR}\left(\mathrm{v}_{\max }, \mathrm{cm}^{-1}\right)$ : 2372, 2319. ${ }^{1} \mathrm{H}$ NMR (300 MHz, $\left.\mathrm{CDCl}_{3}\right): \delta 7.30-7.04(20 \mathrm{H}, \mathrm{m}), 6.20(2 \mathrm{H}, \mathrm{s}), 4.57(2 \mathrm{H}, \mathrm{d}, J 7.5$ $\mathrm{Hz}), 2.86(6 \mathrm{H}, \mathrm{s}), 2.70-2.65(2 \mathrm{H}, \mathrm{m}), 2.45-2.36(2 \mathrm{H}, \mathrm{m}), 1.82-1.63(6 \mathrm{H}, \mathrm{m}), 1.24-1.08(8 \mathrm{H}, \mathrm{m})$, 0.10-0.06 (2H, m). ${ }^{13} \mathrm{C}$ NMR $\left(75 \mathrm{MHz}, \mathrm{CDCl}_{3}\right): \delta 142.5,141.5,139.6,130.3,129.7,127.2$, $126.9,85.9,67.3,53.3,51.5,50.8,35.5,26.2,24.3,22.3$. HRMS: calculated for $\left[\mathrm{C}_{43} \mathrm{H}_{50} \mathrm{~N}_{4} \mathrm{O}_{2}\right]^{+}$ 654.3934; found: 654.3941.

Bis-hydrazone 5b. Following the general procedure, column chromatography (30:1 Hexane$\left.\mathrm{Et}_{2} \mathrm{O}\right)$ afforded $\mathbf{5 b}(1.3 \mathrm{~g}, 77 \%)$ as a yellow oil. $[\alpha]^{20}{ }_{\mathrm{D}}-161.6\left(\mathrm{c} 1.1, \mathrm{CHCl}_{3}\right)$. IR $\left(v_{\max }, \mathrm{cm}^{-1}\right)$ : 2944, 1087. ${ }^{1} \mathrm{H}$ NMR (300 MHz, $\left.\mathrm{CDCl}_{3}\right): \delta$ 7.28-6.30 (20H, m), $5.92(2 \mathrm{H}, \mathrm{s}), 4.76-4.70$ (4H, m), 2.40-2.31 (4H, m), 1.76-1.59 (4H, m), 1.35-1.09 (8H, m). $\left.{ }^{13} \mathrm{C} \mathrm{NMR} \mathrm{(75} \mathrm{MHz,} \mathrm{CDCl}_{3}\right): \delta 144.2$, 140.0, 128.1, 126.5, 126.3, 65.0, 52.9, 35.0, 31.5, 23.6. HRMS: calculated for $\left[\mathrm{C}_{39} \mathrm{H}_{42} \mathrm{~N}_{4} \mathrm{Na}\right]^{+}$ 589.3307; found: 589.3323 .

Bis-hydrazone 5c. Following the general procedure, column chromatography (30:1 Hexane$\left.\mathrm{Et}_{2} \mathrm{O}\right)$ afforded $\mathbf{5 c}(926 \mathrm{mg}, 52 \%)$ as a yellow oil. $[\alpha]^{20}{ }_{\mathrm{D}}-95.6\left(c 1.1, \mathrm{CHCl}_{3}\right)$. IR $\left(v_{\max }, \mathrm{cm}^{-1}\right)$ : 2937, 1087. ${ }^{1} \mathrm{H}$ NMR (300 MHz, $\left.\mathrm{CDCl}_{3}\right): \delta$ 7.32-7.16 (20H, m), $6.51(2 \mathrm{H}, \mathrm{s}), 4.62(2 \mathrm{H}, \mathrm{t}, J 5.7$ $\mathrm{Hz}), 1.99-1.94(8 \mathrm{H}, \mathrm{m}), 1.64-1.57(4 \mathrm{H}, \mathrm{m}), 1.34-1.17(8 \mathrm{H}, \mathrm{m}) .{ }^{13} \mathrm{C} \mathrm{NMR}\left(75 \mathrm{MHz}, \mathrm{CDCl}_{3}\right): \delta$ 144.0, 142.8, 128.2 128.0, 127.8, 126.1, 60.6, 53.6, 34.8, 29.7, 23.8, 19.4. HRMS: calculated for $\left[\mathrm{C}_{41} \mathrm{H}_{46} \mathrm{~N}_{4} \mathrm{Na}\right]^{+}$617.3620; found: 617.3640.

\section{General procedure for the synthesis of pyridine bis-hydrazones (7)}

Pyridine-2,6-dicarbaldehyde $(6,575 \mathrm{mg}, 4.2 \mathrm{mmol})$ was added, in portions over one hour, to a solution of hydrazine $(8.4 \mathrm{mmol})$ in $\mathrm{MeOH}(10 \mathrm{~mL})$ at room temperature. After two hours stirring, the solvent was removed under reduced pressure, and the residue was purified by FC on silica gel (Hexane/ $\mathrm{Et}_{2} \mathrm{O}$ ) affording the pure pyridine bis-hydrazone.

Pyridine bis-hydrazone 7a. Following the general procedure, column chromatography (4:1 Hexane- $\left.\mathrm{Et}_{2} \mathrm{O}+1 \% \mathrm{Et}_{3} \mathrm{~N}\right)$ afforded $7 \mathbf{a}(1.1 \mathrm{~g}, 76 \%)$ as an orange oil. $[\alpha]^{20}{ }_{\mathrm{D}}-245.2$ (c 1.1, $\left.\mathrm{CHCl}_{3}\right) .{ }^{1} \mathrm{H} \mathrm{NMR}\left(500 \mathrm{MHz}, \mathrm{CDCl}_{3}\right): \delta 7.60(\mathrm{~d}, 2 \mathrm{H}, J 7.7 \mathrm{~Hz}), 7.52(\mathrm{t}, 1 \mathrm{H}, J 7.7 \mathrm{~Hz}), 7.25(\mathrm{~s}$, 2H), 3.79-3.76 (m, 2H), $3.68(\mathrm{dd}, 2 \mathrm{H}, J$ 9.4, 3.7 Hz), 3.51 (dd, 2H, J 9.4, 7.1 Hz), 3.48-3.42 (m, 
2H), $3.40(\mathrm{~s}, 6 \mathrm{H}), 3.16-3.12(\mathrm{~m}, 2 \mathrm{H}), 2.06-1.89(\mathrm{~m}, 8 \mathrm{H}) .{ }^{13} \mathrm{C} \mathrm{NMR}\left(75 \mathrm{MHz}, \mathrm{CDCl}_{3}\right): \delta 155.5$, 136.0, 132.0, 115.8, 74.4, 62.8, 59.3, 48.6, 26.9, 22.3. HRMS: calculated for $\left[\mathrm{C}_{19} \mathrm{H}_{30} \mathrm{~N}_{5} \mathrm{O}_{2}\right]^{+}$ 360.2400; found: 360.2401 .

Pyridine bis-hydrazone $\mathbf{7 b}$. Following the general procedure, column chromatography $(3: 1: 1$ Hexane- $\left.\mathrm{Et}_{2} \mathrm{O}-\mathrm{CH}_{2} \mathrm{Cl}_{2}+1 \% \mathrm{Et}_{3} \mathrm{~N}\right)$ afforded $7 \mathbf{b}(1.7 \mathrm{~g}, 74 \%)$ as a yellow solid. $\mathrm{mp} 172-173{ }^{\circ} \mathrm{C}$. $[\alpha]^{20}{ }_{\mathrm{D}}-354.2\left(c\right.$ 1.2, $\left.\mathrm{CHCl}_{3}\right) .{ }^{1} \mathrm{H}$ NMR $\left(300 \mathrm{MHz}, \mathrm{CDCl}_{3}\right): \delta 7.35-7.19(\mathrm{~m}, 23 \mathrm{H}), 6.90(\mathrm{~s}, 2 \mathrm{H})$, $5.19(\mathrm{~d}, 4 \mathrm{H}, J 6.5 \mathrm{~Hz}), 2.62-2.45(\mathrm{~m}, 4 \mathrm{H}), 1.93-1.71(\mathrm{~m}, 4 \mathrm{H}) .{ }^{13} \mathrm{C} \mathrm{NMR}\left(75 \mathrm{MHz}, \mathrm{CDCl}_{3}\right): \delta$ 155.4, 143.0, 135.7, 131.8, 128.5, 126.8, 126.2, 115.9, 65.1, 31.4. HRMS: calculated for $\left[\mathrm{C}_{39} \mathrm{H}_{38} \mathrm{~N}_{5}\right]^{+}$576.3127; found: 576.3151 .

Pyridine bis-hydrazone 7c. Following the general procedure, column chromatography (3:1 Hexane-Et $\left.{ }_{2} \mathrm{O}+1 \% \mathrm{Et}_{3} \mathrm{~N}\right)$ afforded $7 \mathrm{c}(1.5 \mathrm{~g}, 60 \%)$ as a yellow solid. mp 171-172 ${ }^{\circ} \mathrm{C} .[\alpha]^{20}{ }_{\mathrm{D}}$ -212.5 (c 1.0, $\left.\mathrm{CHCl}_{3}\right) .{ }^{1} \mathrm{H}$ NMR $\left(300 \mathrm{MHz} \mathrm{CDCl}_{3}\right): \delta 7.35-7.15(\mathrm{~m}, 23 \mathrm{H}), 6.94(\mathrm{~s}, 2 \mathrm{H}), 5.05(\mathrm{t}$, $4 \mathrm{H}, J 5.7 \mathrm{~Hz}), 2.11-2.06(\mathrm{~m}, 8 \mathrm{H}), 1.61-1.56(\mathrm{~m}, 4 \mathrm{H}) .{ }^{13} \mathrm{C} \mathrm{NMR}\left(75 \mathrm{MHz}, \mathrm{CDCl}_{3}\right): \delta 157.6$, $141.3,135.7,131.3,128.2,127.8,126.6,116.0,60.9,31.3,18.7$. HRMS: calculated for $\left[\mathrm{C}_{41} \mathrm{H}_{42} \mathrm{~N}_{5}\right]^{+}$604.3440; found: 604.3449 .

Pyridine bis-hydrazone 7d. Following the general procedure, column chromatography (3:1 Hexane-Et $\left.{ }_{2} \mathrm{O}+1 \% \mathrm{Et}_{3} \mathrm{~N}\right)$ afforded $7 \mathbf{d}(1.1 \mathrm{~g}, 80 \%)$ as a yellow oil. $[\alpha]^{20}{ }_{\mathrm{D}}+20.6\left(c\right.$ 1.0, $\left.\mathrm{CHCl}_{3}\right)$. ${ }^{1} \mathrm{H}$ NMR $\left(300 \mathrm{MHz}, \mathrm{CDCl}_{3}\right): \delta 7.60-7.47(\mathrm{~m}, 3 \mathrm{H}), 7.25(\mathrm{~s}, 2 \mathrm{H}), 3.91-3.85(\mathrm{~m}, 4 \mathrm{H}), 2.20-2.16(\mathrm{~m}$, $4 \mathrm{H}), 1.57-1.55(\mathrm{~m}, 4 \mathrm{H}), 1.22(\mathrm{~d}, 12 \mathrm{H}, J 6.3 \mathrm{~Hz}) .{ }^{13} \mathrm{C} \mathrm{NMR}\left(75 \mathrm{MHz}, \mathrm{CDCl}_{3}\right): \delta 156.0,135.8$, 130.4, 114.8, 55.4, 29.5, 18.4. MS, $m / z(\%) 350\left(\mathrm{C}_{19} \mathrm{H}_{29} \mathrm{~N}_{5} \mathrm{Na}, 100\right), 328\left(\mathrm{C}_{19} \mathrm{H}_{29} \mathrm{~N}_{5}+\mathrm{H}, 50\right)$, HRMS: calculated for $\left[\mathrm{C}_{19} \mathrm{H}_{29} \mathrm{~N}_{5}\right]^{+} 327.2423$; found: 327.2405 .

General procedure for the Lewis acid-catalyzed Diels-Alder reaction of (E)-3-(but-2enoyl)oxazolidin-2-one (8) with cyclopenta-1,3-diene (9)

A mixture of $\mathrm{M}(\mathrm{OTf})_{\mathrm{x}}(0.02 \mathrm{mmol}, 10 \mathrm{~mol} \%)$ and activated $4 \AA$ molecular sieves $(15 \mathrm{mg})$ was heated in vacuo at $50{ }^{\circ} \mathrm{C}$ for $30 \mathrm{~min}$. The mixture was cooled to room temperature, a solution of ligand $(0.022 \mathrm{mmol}, 11 \mathrm{~mol} \%)$ in solvent $(0.5 \mathrm{~mL})$ was added under Argon. After $30 \mathrm{~min}$. stirring, a solution of (E)-3-(but-2-enoyl)oxazolidin-2-one $(\mathbf{8}, 31 \mathrm{mg}, 0.2 \mathrm{mmol})$ in solvent $(0.5$ $\mathrm{mL})$ was added. After $30 \mathrm{~min}$. stirring, freshly distilled cyclopenta-1,3-diene $(\mathbf{9}, 52 \mu \mathrm{L}, 0.8$ mmol) was added and the mixture was stirred for 90 hours. Column chromatography (HexaneEtOAc) afforded cycloadduct 10. Diastereomeric and enantiomeric ratios were determined by HPLC analysis [Chiralcel OD, 2-propanol:hexane 1:99, $1.0 \mathrm{~mL} / \mathrm{min}, 25{ }^{\circ} \mathrm{C}, t_{r}$ (exo) $31.2 \mathrm{~min}$, $t_{r}($ endo, $1 S, 2 S, 3 R, 4 R) 37.1 \mathrm{~min}, t_{r}($ endo, $\left.1 R, 2 R, 3 S, 4 S) 40.8 \mathrm{~min}\right]$.

\section{Acknowledgements}

We are grateful to the "Ministerio de Ciencia e Innovación" (CTQ2010-15297, CTQ201014974), EU "FEDER" fonds and "Junta de Andalucía" (2008/FQM-3833 and 2009/FQM-4537) 
for financial support. D. M. thanks the "Ministerio de Ciencia e Innovación" for a "Juan de la Cierva" contract.

\section{References}

1. (a) Jacobsen, E. N.; Pfaltz, A.; Yamamoto, H., Eds. Comprehensive Asymmetric Catalysis, Springer, 1999. (b) Mikami, K.; Lautens, M. Eds. New Frontiers in Asymmetric Catalysis, Wiley-VCH: New York, 2007. (c) Ojima, I. (Ed.) Catalytic Asymmetric Synthesis, 2a Ed. Wiley-VCH: New York, 2000. (d) Noyori, R. Science 1990, 248, 1194. (e) Kitamura, M.; Nakatsuka, H. Chem. Commun. 2011, 47, 842.

2. General reviews on N-based ligands: (a) Togni, A.; Venanzi, L. M. Angew. Chem., Int. Ed. 1994, 33, 497. (b) Fache, F.; Schulz, E.; Tommasino, M. L.; Lemaire, M. Chem. Rev. 2000, 100, 2159. (c) Caputo, C. A.; Jones, N. D. Dalton Trans. 2007, 4627. Review on diazaligands: (d) Lemaire, M.; Mangeney, P. "Chiral Diaza-Ligands for Asymmetric Synthesis" in Topics in Organometallic Chemistry, Vol. 15, Springer, Berlin, 2005, pp. 1-301. Review on bis(imino)pyridines: (e) Gibson, V. C.; Redshaw, C.; Solan, G. A. Chem. Rev. 2007, 107, 1745.

3. Chelucci, G.; Thummel, R. P. Chem. Rev. 2002, 102, 3129.

4. Reviews on salen: (a) Larrow, J. F.; Jacobsen, E. N. Topics in Organometallic Chemistry, 2004, 6 (Organometallics in Process Chemistry), 123. Springer Berlin / Heidelberg. (b) Jacobsen, E. N. Acc. Chem. Res. 2000, 33, 421. (c) Taylor, M. S.; Jacobsen, E. N. J. Am. Chem. Soc. 2003, 125, 11204, and references therein.

5. Reviews on bis-oxazolines in asymmetric catalysis: (a) Ghosh, A. K.; Mathivanan, P.; Cappiello, J. Tetrahedron: Asymmetry 2000, 11, 2455. (b) Desimoni, G.; Faita, G.; Jørgensen, K. A. Chem. Rev. 2006, 106, 3561.

6. Review on pyridine bis-oxazolines in asymmetric catalysis: (a) Desimoni, G.; Faita, G.; Quadrelli, P. Chem. Rev. 2003, 103, 3119. Selected new examples: (b) Oelke, A. J.; Sun, J.; Fu, G. C. J. Am. Chem. Soc. 2012, 134, 2966. (c) Parsons, A. T.; Smith, A. G.; Neel, A. J.; Johnson, J. S. J. Am. Chem. Soc. 2010, 132, 9688. (d) Singh, P. K.; Singh, V. K. Org. Lett. 2010, 12, 80. (e) Zhao, J.-F.; Tsui, H.-Y.; Wu, P.-J.; Lu, J.; Loh, T.-P. J. Am. Chem. Soc. 2008, 130, 16492. (f) Milczek, E.; Boudet, N.; Blakey, S. Angew. Chem., Int. Ed., 2008, 47, 6825. (g) Jankowska, J.; Paradowska, J.; Rakiel, B.; Mlynarski, J.; J. Org. Chem. 2007, 72, 2228.

7. (a) Fernández, R.; Lassaletta, J. M. Synlett 2000, 1228 and references therein. (b) Brehme, R.; Enders, D.; Fernández, R.; Lassaletta, J. M. Eur. J. Org. Chem. 2007, 5629. Nucleophilic reactivity: (c) Monge, D.; Martín-Zamora, E.; Vázquez, J.; Alcarazo, M.; Álvarez, E.; Fernández, R.; Lassaletta, J. M. Org. Lett. 2007, 9, 2867. (d) Herrera, R. P.; Monge, D.; Martín-Zamora, E.; Fernández, R.; Lassaletta, J. M. Org. Lett. 2007, 9, 3303. Imine-like reactivity: (e) Fernández, R.; Ferrete, A.; Lassaletta, J. M.; Llera, J. M.; Monge, A. Angew. 
Chem., Int. Ed., 2000, 39, 2893. (f) Fernández, R.; Ferrete, A.; Lassaletta, J. M.; Llera, J. M.; Martín-Zamora, E. Angew. Chem., Int. Ed., 2002, 41, 832.

8. (a) Enders, D.; Fey, P.; Kipphardt, H. Organic Syntheses 1987, 65, 173. (b) Enders, D.; Kipphardt, H.; Gerdes, P.; Breña-Valle, L. J.; Buhshan, V. Bull. Soc. Chim. Belg., 1988, 97, 691.

9. (a) Defoin, A.; Brouillard-Poichet, A.; Streith, J. Helv. Chim. Acta, 1991, 74, 103. (b) Enders, D.; Wiedeman, J. Synthesis, 1996, 1443.

10. (a) Enders, D.; Maaßen, R.; Runsink, J. Tetrahedron: Asymmetry, 1998, 2155 and references cited therein. (b) Yamamoto, Y.; Hoshino, Y.; Fujimoto, Y.; Ohmoto, J. Synthesis, 1993, 298.

11. Application on $\operatorname{Pd}(0)$ catalyzed allylic substitution: (a) Mino, T.; Shiotsuki, M.; Yamamoto, N.; Suenaga, T.; Sakamoto, M.; Fujita, T.; Yamashita, M. J. Org. Chem. 2001, 66, 1795. (b) Mino, T.; Ogawa, T.; Yamashita, M. J. Organomet. Chem. 2003, 665, 122. (c) Mino, T.; Segawa, H.; Yamashita, M. J. Organomet. Chem. 2004, 689, 2833. (d) Enders, D.; Peters, R.; Lochtman, R.; Runsink, J. Eur. J. Org. Chem. 2000, 6, 2839. Application on addition of diethylzinc to aldehydes: (e) Mino, T.; Suzuki, A.; Yamashita, M.; Narita, S.; Shirae, Y.; Sakamoto, M.; Fujita, T. J. Organomet. Chem. 2006, 691, 4297.

12. Lassaletta, J. M.; Alcarazo, M.; Fernández, R. Chem. Commun., 2004, 298.

13. Bermejo, A.; Ros, A.; Fernández, R.; Lassaletta, J. M. J. Am. Chem. Soc. 2008, 130, 15798.

14. A direct correlation between catalytic activity and electronic density of 1,4-diazabutadiene ligands has been noticed: Grasa, G. A.; Hillier, A. C.; Nolan, S. P. Org. Lett. 2001, 3, 1077.

15. Selected examples: (a) Prakash, M.; Kesavan, V. Org. Lett. 2012, 14, 1896. (b) Evans, D. A.; Fandrick, K. R.; Song, H.-J.; Scheidt, K. A. Xu, R. J. Am. Chem. Soc. 2007, 129, 10029. (c) Evans, D. A.; Wu, J. J. Am. Chem. Soc. 2005, 127, 8006. (d) Evans, D. A.; Aye, Y. J. Am. Chem. Soc. 2006, 128, 11034. (e) Sammis, G. M.; Danjo, H.; Jacobsen, E. N. J. Am. Chem. Soc. 2004, 126, 9928. (f) Keith, J. M.; Jacobsen, E. N. Org. Lett. 2004, 6, 153.

16. Braunstein, P.; Boag, N. M. Angew. Chem. Int. Ed. 2001, 40, 680.

17. Aldous, D. J.; Dutton W. M.; Steel, P. G. Tetrahedron: Asymmetry, 2000, 11, 2455.

18. Fernández, R.; Ferrete, A.; Llera, J. M.; Magriz, A.; Martín, E.; Díez, E.; Lassaletta, J. M. Chem. Eur. J. 2004, 10, 737.

19. Domin, D.; Benito-Garagorri; D.; Mereiter, K.; Fröhlich, J.; Kirchner, K. Organometallics 2005, 24, 3957.

20. (a) Carruthers, W. "Cycloadditions Reactions in Organic Synthesis". Tetrahedron Organic Chemistry Series Vol. 8; Pergamon Press: Elmsford, NY, 1990. (b) Nicolau, K. C.; Snyder, S. A.; Montagnon, T.; Vassilikogiannakis, G. Angew. Chem. Int. Ed. 2002, 41, 1668. First diastereoselective version employing chiral $\alpha, \beta$-unsaturated $N$-acyloxazolidinones: (c) Evans, D.; Chapman, K.; Bisaha, J. J. Am. Chem. Soc. 1988, 110, 1238. Examples on enantioselective versions employing Evans N-acyloxazolidinones: (d) Narasaka, K.; Iwasawa, N.; Inoue, M.; Yamada, T.; Nakashima, M.; Sugimori, J. J. Am. Chem. Soc. 1989, 111, 5340. (e) Pikul, S.; Corey, E. J. Org. Synth. 1991, 71, 22. (f) Corey, E. J.; Imwinkelried, 
R.; Pukul, S. J. Am. Chem. Soc. 1989, 111, 5493. (g) Corey, J.; Imai, N.; Zhang, Y. J. Am. Chem. Soc. 1991, 113, 728. (h) Evans, D.; Miller, S.; Lectka, T. J. Am. Chem. Soc. 1993, 115, 6460. (i) Evans, D. A.; Miller, S. J.; Lectka, T.; Matt, P. J. Am. Chem. Soc. 1999, 121, 7559. (j) Atodiresei, I.; Schiffers, I.; Bolm, C. Tetrahedron: Asymmetry 2008, 19, 998.

21. (a) He, S.; Kozmin, S. A.; Rawal, V. H. J. Am. Chem. Soc. 2000, 122, 190. (b) Ros, A.; Álvarez, E.; Dietrich, H.; Fernández, R.; Lassaletta, J. M. Synlett 2005, 2899. (c) Ros, A.; Díez, E.; Marqués-López, E.; Martín-Zamora, E.; Vázquez, J.; Iglesias-Sigüenza, J.; Pappalardo, R. R.; Álvarez, E.; Lassaletta, J. M.; Fernández, R. Tetrahedron: Asymmetry 2008, 19, 998.

22. Evans, A. D.; Miller, S. J.; Lectka, T.; Von Matt, P. J. Am. Chem. Soc. 1999, 121, 7559. 